\title{
Pé Plano: Tratamento pela Técnica de Koutsogiannis modificada
}

\author{
Pes planovalgus management using the modified Koutsogiannis Technique
}

\author{
Guaracy Carvalho Filho(1), Alceu Gomes Chueire ${ }^{(2)}$, Helencar lgnácio(3), \\ Adriano Barros de Aguiar Leonard (4), Luciano Barboza de Souza ${ }^{(4)}$, Reinaldo Oliveira Seleti( ${ }^{(4)}$
}

\section{RESUMO}

O objetivo do estudo foi avaliar a osteotomia calcaneana de deslizamento medial de Koutsogiannis modificada, sob parâmetros clínicos e radiográficos. Entre janeiro de 1997 e abril de 2001, vinte e nove pés de dezenove pacientes portadores de pé plano valgo flexível idiopático, com idade média de 11,36 anos, foram submetidos ao procedimento de Koutsogiannis modificado pela varização da extremidade deslizada, com um seguimento médio de dezesseis meses. A cirurgia foi indicada para pacientes com sintomas de dor e fadiga e portadores de deformidade. Clinicamente, dezessete pacientes referiram estar sem dor e dezesseis não apresentaram deformidade residual, sendo notada a correção da deformidade do retropé. Obteve-se 9,36 em média na análise dos resultados subjetivos pós-operatórios, cuja graduação era de 0-10. Dois maus resultados de dor e persistência da deformidade foram atribuídos a portadores de hiperfrouxidão ligamentar, com deformidade grave préoperatória. O estudo radiográfico revelou, na incidência lateral, decréscimo dos valores médios pré-operatórios dos ângulos talocalcaneano e talo-primeiro metatarso de 29,7 e 11,33 graus para valores pós-operatórios de 23,05 e 7,76 graus respectivamente. Na incidência antero-posterior notou-se decréscimo do valor médio do ângulo talocalcaneano de 36,39 para 35,42 graus. Concluiu-se que o procedimento de Koutsogiannis mostrou-se eficaz para o tratamento de pacientes de dez a treze anos, portadores de pé plano valgo flexível idiopático leve e moderado, apresentando melhoria estética, alívio sintomático e melhora radiográfica.

Descritores: Pé Plano; Cirurgia; Clacâneo; Osteotomia.

\section{SUMMARY}

The objective of this study was to investigate the modified Koutsogiannis medial slipped calcaneal osteotomy using clinical and radiographic parameters. From January 1997 through April 2001, twenty-nine feet of nineteen patients with idiopathic flexible pes planovalgus, whose mean age was 11.36 years, underwent the modified Koutsogiannis procedure to correct the slipped varus deformity, with an average follow-up period of sixteen months. Surgery was prescribed to patients presenting pain and fatigue symptoms, as well as any deformities. Clinically, seventeen patients reported absence of pain and sixteen did not present residual deformity, the correction of the deformity being noticed in the hind foot. In a 0-10 scale, the average value of the post-operative subjective results was of 9.36. Two poor results (pain and deformity resistance) were associated with ligamental hyperlaxity, with severe pre-operative deformity. Lateral view radiographs revealed a decrease in the pre-operative mean values of the talocalcaneal and talar-first metatarsal angles, from 29.7 and 11.33 degrees to 23.05 and 7.76 degrees, respectively, in the post-operative period. Anteroposterior view radiographs showed a decrease in the mean value of the talocalcaneal angle, from 36.39 to 35.42 degrees. The conclusion was that the Koutsogiannis procedure showed to be effective in the management of patients in the 1-13 year age group with mild to moderate idiopathic flexible pes planovalgus, presenting esthetic improvement, symptom relief and radiographic improvement.

Key words: Flatfoot; Surgery; Calcaneus; Osteotomy.

\footnotetext{
Trabalho realizado no Departamento de Ortopedia e Traumatologia do Hospital d Base da Faculdade de Medicina de São José do Rio Preto - FAMERP/FUNFARME

1 - Chefe da Disciplina de Ortopedia e Traumatologia

2 - Chefe do Departamento de Ortopedia e Traumatologia

3 - Preceptor dos Médicos Residentes

4 - Ex-Residentes do Serviço de Ortopedia e Traumatologia FAMERP/FUNFARME

Endereço para correspondência: Av. Brigadeiro Faria Lima, 4929, Nova Redentora15090-000-São José do Rio Preto-SP.

E-mail- con@famerp.br ou ortopedia@famerp.br.
}

Study performed at the Department of Orthopedics and Traumatology, Hospital de Base, FAMERP - Faculty of Medicine of Sao Jose do Rio Preto, SP, Brazil

1 - Head of the Discipline of Orthopedics and Traumatology, 2 - Head of the Department of Orthopedics and Traumatology 3 - Preceptor of Residents

4 - Ex-resident

Address: Av. Brigadeiro Faria Lima, 4929 - Nova Redentora Sao Jose do Rio Preto, SP 15090-000 - Brasil - Telefax (55 17) 227-8800 e-mails- con@famerp.br or ortopedia@famerp.br

Trabalho recebido em 21/08/2002. Aprovado em 11/04/2003 


\section{INTRODUÇÃO}

O pé plano flexível é uma entidade comum na prática clínica. Manifesta-se em crianças após a bipedação pela queda do arco plantar longitudinal medial, cabeça do tálus proeminente medial e plantarmente, valgismo do retropé e supinação do antepé(23,10). Embora, apenas 3\% dos pacientes detectados na infância tornar-se-ão dolorosos e incapacitantes na vida adulta, um grande contingente apresenta-se no limiar da normalidade, podendo tornar-se insuficientes e dolorosos quando submetidos à carga ${ }^{(7)}$. Quando o pé plano postural é submetido ao peso corporal, o calcâneo prona abaixo do tálus e sua extremidade anterior roda lateral e dorsalmente, enquanto a cabeça do tálus move-se medial e plantarmente. Os ligamentos calcaneonavicular plantar e interósseo talocalcaneano alongam-se permitindo a eversão do retropé e a abdução do navicular, que move-se juntamente com o antepé, levando o eixo gravitacional para o primeiro raio. A persistência desta postura determina a contratura do tendão calcâneo, que por sua vez, inclina o calcâneo em flexão plantar, perdendo sua inclinação normal(18,22).

O exame radiográfico mostra alterações dos eixos, podendo ser demonstradas por ângulos traçados entre eles. O aumento dos ângulos de Kite (talocalcaneano), Meary (talo-primeiro metatarso) e Moreau-Costa-Bertani (calcâneo-talo-primeiro metatarso) e redução do ângulo calcâneo-solo na incidência em perfil traduzem o desvio plantar do tálus e a queda do arco plantar, respectivamente ${ }^{(1,18,23)}$. Na incidência antero-posterior, a pronação do calcâneo e subluxação da talonavicular são expressos pelo aumento dos ângulos talocalcaneano e talonavicular, respectivamente ${ }^{(1,23)}$.

O tratamento tem por objetivo estacionar a progressão da deformidade, tratar sintomas quando presentes e restabelecer o arco plantar longitudinal medial, com mobilidades e funções normais ${ }^{(18,23)}$. São inúmeras as possibilidades terapêuticas, desde uma simples conduta expectante, associada ou não a exercícios, passando pelo uso de órteses ${ }^{(14)}$, chegando até procedimentos cirúrgicos variados ${ }^{(18)}$.

A correção cirúrgica é indicada na persistência dos sintomas e deformidade após terapia conservadora, causando restrições a atividades cotidianas e desgaste irregular dos calçado ${ }^{(16,23)}$. Didaticamente, os procedimentos cirúrgicos são divididos em três categorias. Na primeira, são realizados procedimentos em partes ósseas como as osteotomias do calcâneo ${ }^{(7,15)}$ e artrodeses ${ }^{(12)}$. Na segunda, aqueles que agem sobre partes moles, como por exemplo, as transferências tendíneas e os reforços ligamentares ${ }^{(8)}$. Na terceira, aqueles que atuam em ambas as partes concomitantemente ${ }^{(7,11)}$.

Um enfoque maior ao retropé tem sido dado nos últimos anos. O valgismo do calcâneo atuaria como fator desencadeante a perpetuador da deformidade, devendo portanto ser corrigido primordialmente por meio de osteotomias calcaneanas ${ }^{(21)}$. A osteotomia calcaneana foi descrita, pela primeira vez, por Gleich em 1893. O procedimento consistia em uma osteotomia oblíqua do polo posterior do calcâneo em cunha medial, permitindo um deslizamento para frente, medial e para baixo. Nápoli(15), preconizou a osteotomia cuneiforme medial do calcâneo com retirada de cunha, associada à tenossuspensão dos tibiais anterior e posterior de Natiello, levando em conta que no pé plano, além do valgismo do calcâneo, haveria também um componente anterior representado pela supinação do antepé. Koutso-

\section{INTRODUCTION}

Flexible flat foot is an ordinary entity in the clinical practice. After they start bipeding, children may manifest a flat foot through the fall of the medial longitudinal plantar arch, medially and plantarly prominent talar head, hind foot valgus and forefoot supination ${ }^{(23,10)}$. Although only $3 \%$ of patients detected in childhood will feel pain and be disabled in adult life, a large population presents in the threshold of normality and may become inadequate and painful when subjected to load (7). When a postural flat foot is subjected to the weight of the body, the calcaneus will pronate below the talus, as its anterior end rotates laterally and dorsally, while the talar head moves both medially and plantarly. The calcaneonavicular plantar and interbone talocalcaneal ligaments will elongate, allowing hind foot eversion and navicular abduction, which then moves together with the forefoot, taking the gravitational shaft to the first radius. The persistence of this posture determines the contracture of the calcaneal tendon that, on its turn, will bend the calcaneus in plantar flexion, loosing its normal inclination ${ }^{(18,22)}$.

Radiograph evaluations show changes in the shafts that may be demonstrated by drawing angles between them. The increase in Kite's (talocalcaneal) angles, Meary's (talar-first metatarsal) angles and Moreau-Costa-Bertani's (calcaneal-talar-first metatarsal) angle, and the reduction of the calcaneal-floor angle in the profile view radiograph translate the plantar talar shift and the fall of the plantar arch, respectively ${ }^{(1,18,23)}$. In the anteroposterior view radiographs, calcaneal pronation and talonavicular subluxation are expressed by the increase in the talocalcaneal and talonavicular angles, respectively ${ }^{(1,23)}$.

The objective of the management is to stop the progression of the deformity, treat symptoms at their onset, and restore the medial longitudinal plantar arch to its normal mobility and functions ${ }^{(18,23)}$. A number of therapeutical possibilities exist, from a simple expectation behavior that may or not be associated to exercise, to the use of ortheses (14) and to various surgical procedures $^{(18)}$.

Surgical correction is prescribed when both symptoms and the deformity persist after conservative therapy, causing restrictions to everyday activities and uneven shoe wear ${ }^{(16,23)}$. Surgical procedures are didactically divided into three categories. In the first, procedures are performed in bone portions, such as calcaneal osteotomies ${ }^{(7,15)}$ and arthrodeses ${ }^{(12)}$. The second category includes procedures focusing on soft parts, as for example, tendon transfers and ligamental reinforcements ${ }^{(8)}$. The third category includes procedures focusing simultaneously on bones and soft parts ${ }^{(7,11)}$.

The hind foot has been more focused during the last few years. Since calcaneal valgus would act as a triggering factor to perpetuate the deformity, it should be primarily corrected by means of calcaneal osteotomies ${ }^{(21)}$. The calcaneal osteotomy was described for the first time by Gleich in 1893. The procedure consisted of a tilted osteotomy of the calcaneal posterior pole in medial wedge, thus allowing medial, forward and downward slipping. In 1971 Napoli ${ }^{(15)}$ proposed the calcaneal medial cuneiform osteotomy with wedge removal associated to Natiello anteroposterior tibial tenosuspension, considering that, besides calcaneal valgus, an anterior component represented by forefoot supination would also exist in a flat floot. In that same year, Koutsogiannis proposed a modification to Gleich's original procedu- 
giannis, no mesmo ano, descreveu uma modificação ao procedimento original de Gleich ao desviar o fragmento posterior e medialmente.

A osteotomia de deslizamento medial que objetiva primariamente a correção do valgismo do retropé, indiretamente recria o arco plantar longitudinal medial(2,10), reduz a tensão sobre ligamentos mediais ${ }^{(17)}$ e aumenta a supinação ativa do calcâneo exercida pelo grupo muscular posterior, melhorando assim a função e aliviando sintomas. A melhor distribuição de carga melhora os sintomas e a função do pé. Suas vantagens incluem a não necessidade de enxertia óssea e uma menor convalescença pós-operatória ${ }^{(2,10)}$. Sua desvantagem está relacionada a não correção da abdução grave do antepé ${ }^{(2,19)}$. Levando este fato em consideração, alguns autores associam ao procedimento a tenossuspensão dos tendões tibiais anterior e posterior ${ }^{(7,15)}$. Estudos em cadáveres apontam ainda alterações da distribuição de carga sobre a articulação tibiotalar que pode predispor a alterações degenerativas ${ }^{(2,13)}$. Atribui-se também a cirurgia como um fator preventivo de dor e disfunção na vida adulta(4,22)

Evans $^{(6)}$ descreveu a osteotomia em cunha de adição realizada no calcâneo, imediatamente atrás da articulação calcaneocuboidea, sendo hoje reservada aos pacientes portadores de excessiva abdução do antepé. O autor acreditava que a principal causa da deformidade era o relativo encurtamento da coluna lateral ${ }^{(1,6)}$. Suas principais vantagens incluem a correção simultânea da abdução do antepé, valgismo de retropé e manutenção da mobilidade articular. Como desvantagens apresenta falha na correção do varo fixo e a necessidade de enxertia óssea $^{(6)}$.

O objetivo do presente estudo é analisar a osteotomia de deslizamento medial do calcâneo de Koutsogiannis modificada, avaliando os resultados clínicos e radiográficos.

\section{CASUÍSTICA E MÉTODO}

Este estudo foi constituído de 19 pacientes, sendo 10 do sexo masculino e 09 do sexo feminino, que apresentavam pé plano valgo flácido idiopático. Destes, 10 pacientes possuíam a deformidade bilateralmente e 09 unilateralmente, totalizando 29 pés tratados cirurgicamente, no período de janeiro de 1997 a abril de 2001 (Tabela 1).

A idade dos pacientes variou de 10 a 13 anos, com uma média de 11 anos e 4 meses. O tempo médio de seguimento foi de 1 ano e 4 meses, variando entre o mínimo de 6 meses e o máximo de 04 anos. Em decorrência dos maus resultados relatados na literatura ${ }^{(1,10,18)}$, excluiu-se do estudo os pacientes que apresentavam pé plano de $3^{\circ}$ e $4^{\circ}$ graus de Vila$\operatorname{dot}^{(25)}$ com alterações importantes na marcha e que apresentavam sintomatologia dolorosa.

$\mathrm{Na}$ análise subjetiva dos resultados pós-operatórios, aplicou-se a todos os pacientes o questionário sub-

re, to include a shift of the fragment, both posteriorly and medially.

The medial slipped osteotomy viewing primarily the correction of hind foot valgus will indirectly recreate the medial longitudinal plantar arch ${ }^{(2,10)}$, reduce the stress in medial ligaments (17) and increase the calcaneal active supination exerted by the posterior muscular group, thus improving the foot's function and relieving symptoms. A more uniform load distribution improves both the symptoms and the foot's function. This has the advantage of not requiring bone grafting and reducing the post-operative convalescence period ${ }^{(2,10)}$. The disadvantage is that it does not correct severe forefoot abductions ${ }^{(2,19)}$. Based on this fact, several authors associate anteroposterior tibial tendon tenosuspension to the procedure ${ }^{(7,15)}$. Also, studies in cadavers show changes in the distribution of load through the tibiotalar joint that might predispose to degenerative changes ${ }^{(2,13)}$. Surgery is also seen as a factor capable of preventing pain and dysfunction in adult life $(4,22)$.

Evans $^{(6)}$ described a calcaneal-cuboid-cuneiform osteotomy performed immediately behind the calcaneal-cuboid joint, which is reserved nowadays to patients with excess forefoot abduction. The author believed that the main cause of deformity was the relative lateral column shortening ${ }^{(1,6)}$. Its main benefits include the simultaneous correction of forefoot abduction, hind foot valgus, and the preservation of joint mobility. Disadvantages are that the procedure fails to correct the fixed varus and requires bone grafting ${ }^{(6)}$.

The objective of this study is to analyze the modified Koutsogiannis calcaneal medial slipped osteotomy and evaluate clinical and radiographic results.

\section{CASES AND METHOD}

This study included a total of 19 patients (10 males and 9 females) with idiopathic flexible pes planovalgus. Ten patients had bilateral deformities and 9 had unilateral deformities. A total of 29 feet were surgically treated from January 1997 to April 2001 (Table 1).

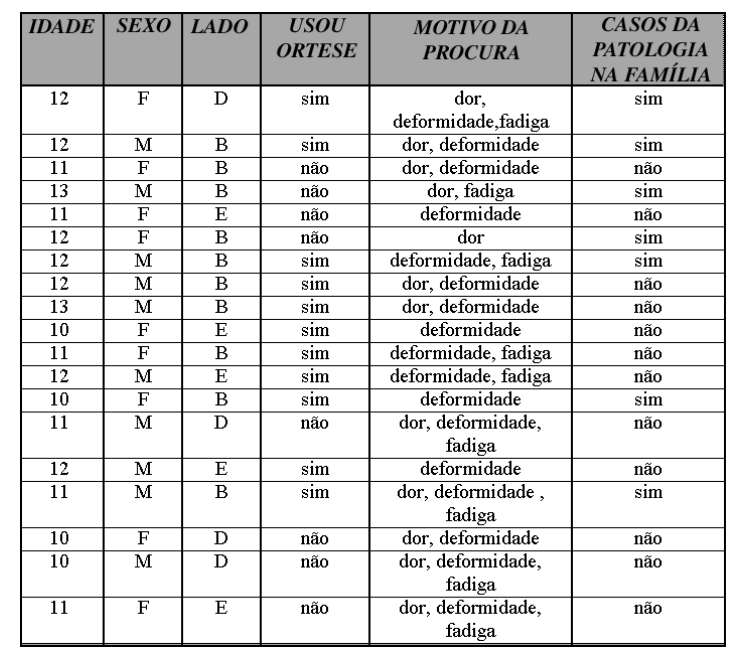

$B$, bilateral; $D$, direito; $E$, esquerdo $B$, bilateral; $R$, right; $L$, left

Tabela 1 - Dados Epidemiológicos Table 1 - Epidemiologic data
The patients' age group was 10 13 years, with a mean age of 11 years and 4 months. The mean followup time was 1 year and 4 months, with a minimum of 6 months and a maximum of 4 years. Based on the poor results reported in literature $(1,10,18)$, patients with Viladot $3^{\text {rd }}$ and $4^{\text {th }}$ degrees flat feet ${ }^{(25)}$ with relevant gait alterations and painful symptoms were excluded from the study.

In a subjective analysis of postoperative results, the modified Mahan and McGlancy subjective questionnaire was applied to each patient $t^{(1)}$.

Ten (52.63\%) patients searched for medical attendance due to pain and deformity, seven (42.1\%) due to deformity only, and (10.52\%) due to isolated pain. Twelve (63.15\%) patients had used ortheses previous to 
jetivo de Mahan e Mc Glancy modificado $^{(1)}$.

A procura pelo serviço médico foi por dor e deformidade em dez pacientes $(52,63 \%)$, sete $(42,1 \%)$ somente por deformidade e dois $(10,52 \%)$ devido a dor isolada. Doze pacientes (63,15\%) fizeram uso de órteses antes da cirurgia. Botas ortopédicas com palmilhas foram as mais prescritas. Não foi encontrada, nesta casuística, tendência familiar ao pé plano valgo, pois doze pacientes $(68,42 \%)$ negaram história familiar desta patologia. Não houve predileção ao lado afetado, pois cinco pacientes $(26,31 \%)$ apresentaram a patologia do lado direito, quatro do lado esquerdo $(21,05 \%)$ e dez pacientes $(52,63 \%)$ em ambos os lados, notando-se, portanto, índice considerável de bilateralidade (Tabela 1).

A hiperfrouxidão ligamentar estava presente em dez pacientes $(52,63 \%)$ e a formação do arco plantar medial ao ficar na ponta dos pés não foi observada em nove indivíduos $(47,36 \%)$.

A avaliação radiográfica foi realizada por meio das incidências ântero-posterior e perfil ortostáticos dos pés e medidos os ângulos talocalcaneano (Kite) na incidência ântero-posterior (valores normais de 25 a $30^{\circ}$ ) (Figura 1) e perfil (valores normais de 35 a $50^{\circ}$ ) (Figura 2) e taloprimeiro metatarso (Meary) no perfil (valores normais de 0 a $1^{\circ}$ ) (Figura 3), comparando-os pré e pós-operatoriamente.

\section{TÉCNICA CIRÚRGICA}

O paciente era posicionado pronado com o joelho fletido $30 \mathrm{a} 45^{\circ} \mathrm{sob}$ anestesia raquidiana. Após esvaziamento venoso mantido por faixas elásticas tipo Esmarch ao nível da coxa, uma incisão era feita na face lateral do retropé e imediatamente posterior aos tendões fibulares, estendendo-se proximalmente desde a margem lateral do tendão calcâneo até a face plantar do calcanhar (Figura 4). As margens da incisão eram cuidadosamente descoladas e elevadas, sendo identificados e isolados os tendões fibulares e o ramo sensitivo do nervo sural, mantidos separa-

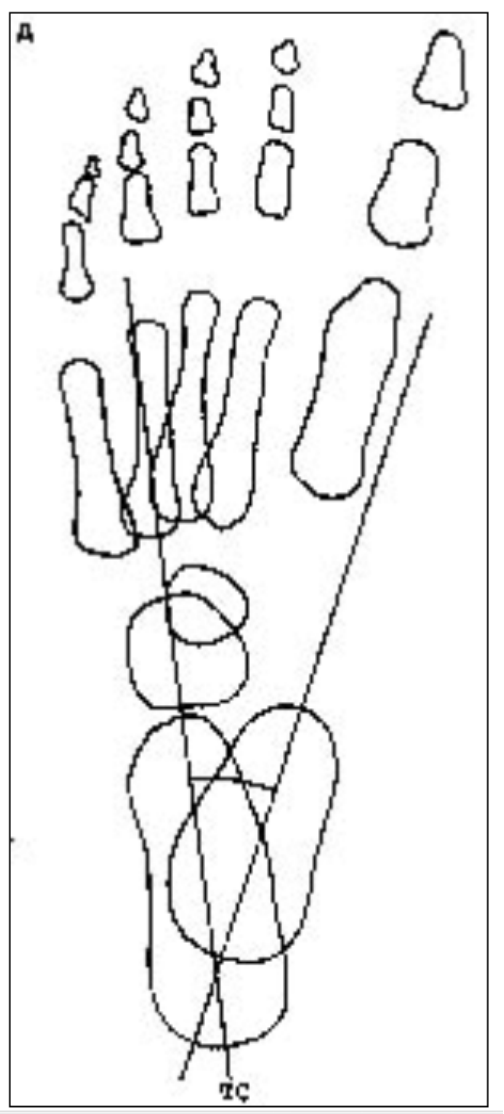

Figura 1 - Ângulo talocalcaneano em $A P$ Figure 1 Talar-calcaneal angle - AP view

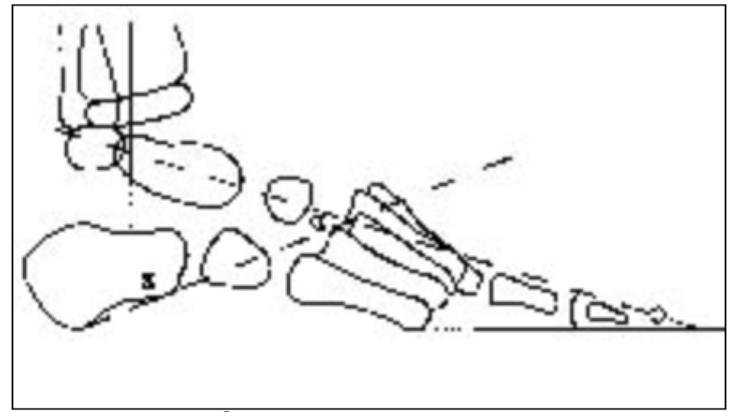

Figura 2 - Ângulo Talocalcaneano. Projeção lateral Figure 2 Talar-calcaneal angle. Lateral view

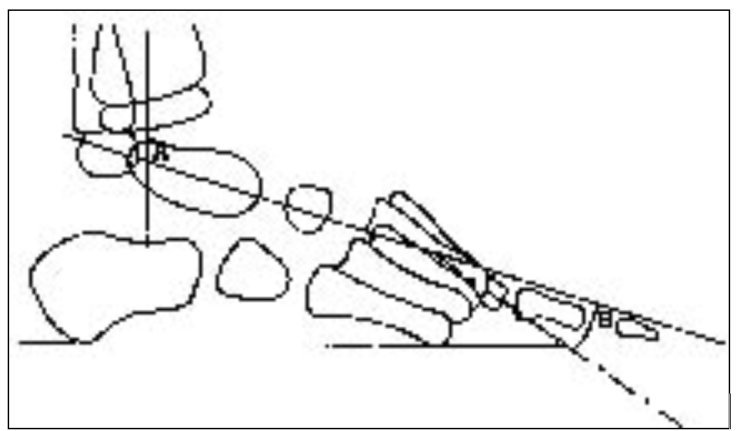

Figura 3 - Ângulo talo-primeiro metatarso. Projeção lateral Figure 3 Talar-first metatarsal angle. Lateral view surgery. Orthopedic shoes with inner soles were the most prescribed ortheses. In these cases no family tendency to have pes planovalgus, since twelve (68.42\%) patients denied having this pathology in their family history. There was no preferred side, since the pathology affected five $(26.31 \%)$ patients in the right side, four $(21.05 \%)$ in the left side, and ten $(52.63 \%)$ in both sides, which mean a significant bilaterality index (Table 1).

Hyperlaxity of ligaments was present in ten patients (52.63\%), and in 9 (47.36\%) only when they tiptoed.

A radiographic evaluation was performed through anteroposterior incidences and ortostatic profiles of the feet; the talar-calcaneal (Kite's) angle was measured in the anteroposterior view radiograph (normal range: $25-30^{\circ}$ ) (Figure 1) and in the profile view radiograph (normal range: $35-50^{\circ}$ ) (Figure 2) and the talarfirst metatarsal (Meary's) angle in the profile view radiograph (normal range: $0-15^{\circ}$ ) (Figure 3), comparing the pre- and post-operative results.

\section{SURGICAL TECHNIQUE}

Under rachidial anesthesia, each patient was placed in a pronated position, with the knee bent to 30 $45^{\circ}$. After venous depletion maintained with the aid of the Esmach type elastic bandages at thigh level, an incision was performed in the lateral face of the hind foot, immediately behind to the fibular tendons, proximally extending from the lateral margin of the calcaneal tendon up to the calcaneal plantar face plantar (Figure 4). The incision margins were carefully separated and lifted, after which the fibular tendons and the sensitive branch of the sural nerve were identified, separated and maintained as such with the aid of an autostatic separator. An incision was performed in the periosteum, which was then lifted, in alignment with the skin incision (Figure 4). The calcaneus was then obliquely sectioned using a wide osteotome largo (Figure 5).

Then the posterior calcaneal fragment was medially shifted until its medial margin became aligned with 
dos por afastador autostático. O periósteo era incisado e elevado em linha com a incisão da pele (Figura 4). Com um osteótomo largo o calcâneo era seccionado obliquamente (Figura 5).

A seguir, o fragmento posterior do calcâneo era desviado medialmente até que sua margem medial estivesse em linha com o sustentáculo do tálus. Geralmente era necessário desviar um terço à metade da largura do calcâneo (técnica original). Neste estudo introduziu-se uma pequena modificação a este passo, visando corrigir também o valgismo do calcâneo, pois, além da migração do fragmento posterior do calcâneo medialmente, houve a sua varização, por meio de uma abertura em cunha lateral sem interposição de enxerto. Os fragmentos do calcâneo foram fixados com um fio de Steinmann (3,0 mm), introduzido obliquamente a partir da face posterior plantar do calcâneo (Figuras 6 e 7).

A incisão era fechada de modo usual e um aparelho gessado suropodálico era aplicado com o tornozelo e pé em posição funcional.

Realizava-se uma abertura no gesso para curativos no $3^{\circ}$ dia pós-operatório. Os pontos eram retirados após duas semanas e era realizado um controle radiográfico. Oito semanas depois da cirurgia, trocava-se o aparelho gessado e retirava-se o fio de Steinmann. Nova avaliação radiográfica era realizada e um aparelho gessado com salto era aplicado por quatro semanas adicionais. Após a retirada do mesmo, prescrevia-se rotineiramente uma palmilha com elevação da abóbada plantar de $18 \mathrm{~mm}$, cunha varizadora de $7 \mathrm{~mm}$ e cunha pronadora de 7 milímetros.

As avaliações objetivas e subjetivas pós-operatórias foram realizadas trimestralmente após a retirada do aparelho gessado durante o primeiro ano pós-operatório, incluindo cicatrização da incisão cirúrgica, dor, alterações na marcha. Radiografias ortostáticas eram obtidas para avaliar a correção radiográfica da deformidade. Após este período, passou-se a acompanhar o paciente anualmente.

\section{RESULTADOS}

\section{A. AVALIAÇÃO CLÍNICA}

$\mathrm{Na}$ análise final do período pós-operatório, dezessete

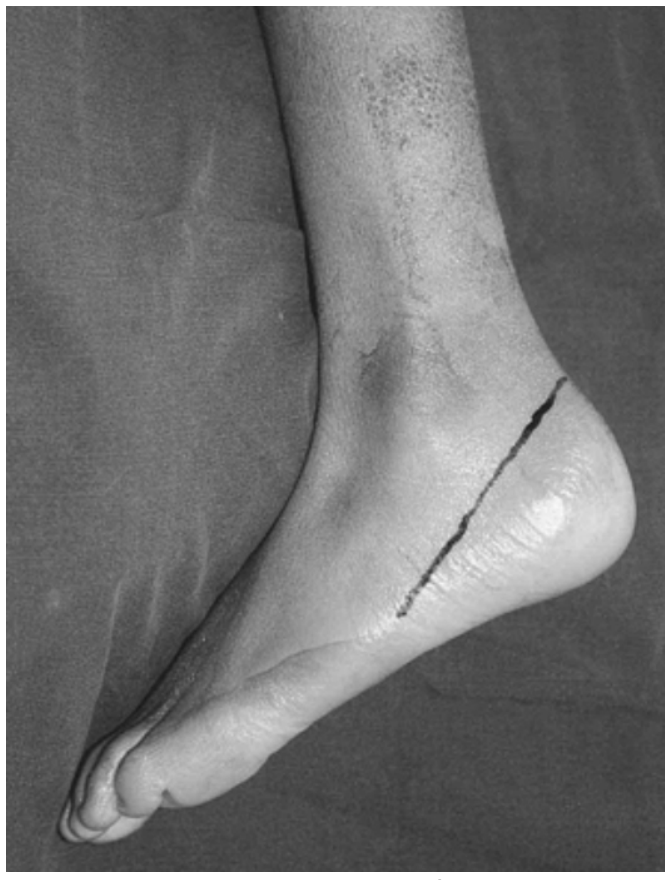

Figura 4 - Incisão cirúrgica

Figure 4 - Surgical incision

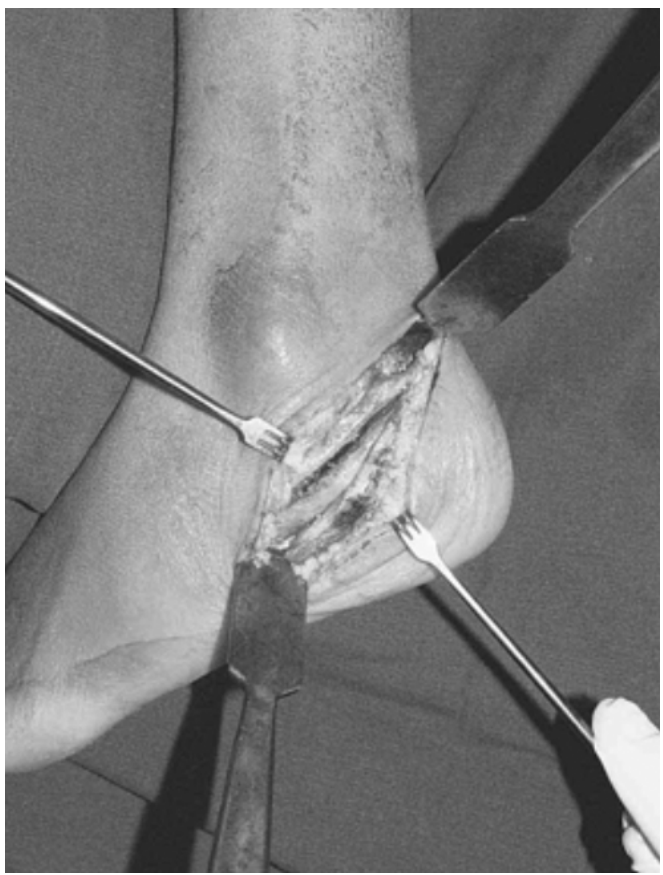

Figura 5 - Descolamento do periósteo Figure 5 - Periosteal lifting the sustentaculum tali. In general, the original technique required that onethird to half the width of the calcaneous was deviated. In this study we introduced a slight modification to this step viewing to correct also the calcaneal valgus deformity, since, besides the medial migration of the calcaneal posterior fragment, this fragment also showed to be varus, using a lateral cuneiform opening wedge without graft insertion. The calcaneal fragments were fixed with Steinmann 3.0- $\mathrm{mm}$ thread obliquely introduced from the calcaneal plantar posterior face (Figures 6 and 7).

The incision was closed in the usual manner and a sural podal plaster splint was employed, with the foot in its functional position.

On Day 3 after the surgery an opening was made in the plaster, for dressing. The stitches were removed after two weeks, when a radiograph control was performed. Eight weeks after the surgery, the plaster splint was changed and the Steinmann thread was removed. A new radiograph evaluation was performed and a heeled plaster splint was applied and maintained for another four weeks. After the splint was removed, an inner sole provided with an 18- $\mathrm{mm}$ lifting of the plantar vault, a 7- $\mathrm{mm}$ wedge to correct varus deformities and a 7-mm wedgeshaped pronator were routinely prescribed

During the first year after the surgery, objective and subjective evaluations were performed quartely after the plaster splint was removed, including surgical incision healing, pain, and alterations of the gait patterns. Ortostatic radiographs were obtained in order to evaluate the deformity correction. Following this period, patients were followed-up annually.

\section{RESULTS}

\section{A. CLINICAL EVALUATION}

In the final analysis of the post-operative period seventeen (89.47\%) patients reported being painless and sixteen (84.21\%) patients showed no residual deformities (Figures 8 and 9).

Most patients (eighteen, 92.3\%) had no claudicant gait. The pre-operative symptoms persisted in two patients, both of whom had ligamental hyperlaxity. No patients showed suture dehiscence, infection and necrosis, hypertrophic scar and other complications due to the surgical wound. 
pacientes $(89,47 \%)$ referiram estar sem dor. Dezesseis pacientes $(84,21 \%)$ não apresentam deformidade residual (Figuras 8 e 9).

A grande maioria, dezoito pacientes (92,3\%), não apresentou marcha claudicante. Em dois pacientes persistiram os sintomas préoperatórios. Ambos possuíam hiperfrouxidão ligamentar. Em nenhum paciente observou-se deiscência de sutura, infecção e necrose, cicatriz hipertrófica e outras complicações da ferida cirúrgica.

Não notou-se, em nenhum paciente, a progressão da deformidade no período pósoperatório. Na graduação de 0-10 do questionário subjetivo de Mahan e Mc Glancy modificado $^{(1)}$, as notas dadas pelos pacientes quanto ao resultado da cirurgia variaram entre 5-10, com média de 9,36 e todos recomendariam a cirurgia para aqueles com igual patologia

\section{B. AVALIAÇÃO RADIOGRÁFICA}

As radiografias realizadas na primeira avaliação, no terceiro mês pós-operatório nas incidências ântero-posterior (AP) e perfil dos pés com carga axial revelaram uma redução média 4,05 graus do ângulo de Kite (talo-calcaneano) (Figura 1). Na projeção lateral, obteve-se a redução do ângulo de Meary (talo-primeiro metatarso ) em 5,2 graus (Tabela 2).

Em relação aos ângulos de Kite, encontrouse média corretiva de 7,84, conforme mostrado na tabela 2 (Figuras 10 e 11).

\section{DISCUSSÃO}

O pé plano valgo postural na infância é bastante freqüente. A dificuldade inicial é determinar se a criança é ou não portadora de um pé plano valgo idiopático. Tipicamente são crianças menores de 2 anos de idade que apresentam graus variáveis de queda do arco plantar medial devido à hipermobilidade articular nesta faixa etária ${ }^{(22,23)}$. Entre 3 e 5 anos, o arco plantar normal forma-se na maioria das pessoas. Estima-se que, por volta dos 10 anos de idade, apenas $4 \%$ da população apresentará pé plano valgo patológico ${ }^{(7,23)}$. Fatores a serem considerados incluem hiperfrouxidão ligamentar e a formação do arco plantar ao ficar na ponta dos pés ${ }^{(16)}$. Koutsogiannis ${ }^{(10)}$ estudando trinta e quatro pés de dezenove pacientes, notou a ausência de formação do arco plantar medial durante o teste da ponta dos pés em seis pacientes $(31,57 \%)$. No presente estudo, houve leve predomínio de portadores de hiperfrouxidão ligamentar (10 casos) e não formação do arco plantar ao ficar na ponta dos pés

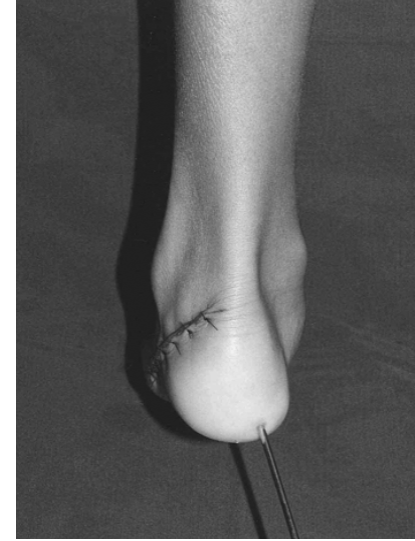

Figura 6 - Fixação calcanena Figure 6 - Calcaneal fixation

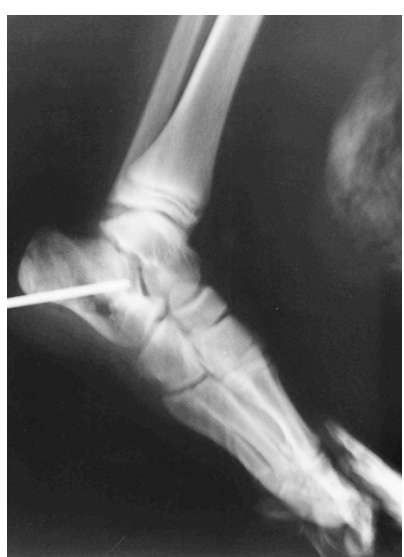

Figura 7 - Aspecto radiográfico pós-operatório

Figure 7 - Post-operative radiographic appearance

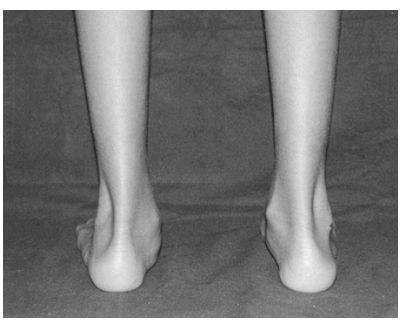

Figura 8 - Aspecto clínico pré-operatório

Figure 8 - Pre-operative clinical appearance

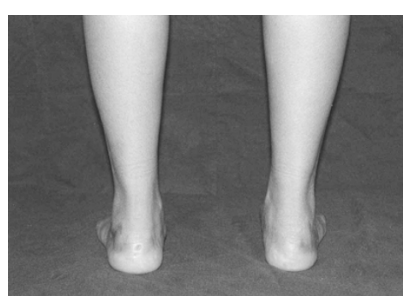

Figura 9 Aspecto clinico em noventa dias pós-operatórios.

Figure 9 - Clinical appearance 90 days after surgery.
No patients presented progression in their deformities during the post-operative period. In the $0-10$ scale of the subjective modified Mahan and McGlancy questionnaire(1), the assessment of surgery results by patients scored between 5 and 10, with an average value of 9.36. All patients stated that they would recommend the surgery to other patients with the same pathology.

\section{B. RADIOGRAPH EVALUATION}

Radiographs obtained in the first evaluation three months after the surgery in anteroposterior $(A P)$ and profile view of axially loaded feet revealed a mean reduction of 4.05 degrees in Kite's (talar-calcaneal) angle) (Figure 1). In the lateral projection, a 5.2-degree reduction in Meary's (talar-first metatarsal) angle was obtained (Table 2).

As to Kite's angle, the mean corrective value found was of 7.84, as shown in Table 2 (Figures 10 and 11).

\section{DISCUSSION}

Postural pes planovalgus is rather frequent in childhood. The early difficulty is to determine whether the child presents idiopathic pes planovalgus. Typically, these children are under 2 years of age and present various degrees of fallen medial plantar arch due to the joint hypermobility showed in this age group ${ }^{(22,23)}$. In most people, the normal plantar arch is formed between 3 and 5 years of age. An estimate is that by the age of 10 , only $4 \%$ of the population will have pathological pes planovalgus ${ }^{(7,23)}$. Factors to be considered include hyperlaxity of ligaments and formation of the plantar arch when tiptoeing ${ }^{(16)}$. In 1971 Koutsogiannis ${ }^{(10)}$ studied 34 feet of 19 patients and noticed a lack of medial plantar arch formation during the tiptoe test in six (31.57\%) patients. In our study, a slight predominance (10 cases) of patients with hyperlaxity of ligaments was found, without plantar arch formation when tiptoeing in 9 cases, showing the low prevalence of severe deformities among patients with postural pes planovalgus.

The search for medical care was due mainly to the fall of the medial plantar arch. Anxious parents believed their children would have abnormal, impaired feet if they were not treated. As a single symptom, pain is uncommon ${ }^{(15,23)}$ and, if present, is found in the tarsal sinus when the child is about 12 years old. Another commonly reported complaint is fatigue ${ }^{(15)}$. This survey showed a higher prevalence of the deformity associated with pain (10 cases), followed by deformity only (8 cases) and just 2 cases due to isolated pain. Fatigue was not an isolated effect, since it 
em 9 casos, demonstrando a baixa prevalência de deformidades graves dentre os portadores do pé plano valgo postural

A procura ao médico deveu-se principalmente, à queda do arco plantar medial. Ansiosos, os pais acreditam tratar-se de um pé anormal e nocivo, caso não seja tratado. Dor como sintoma isolado é incomum ${ }^{(15,23)}$ e quando presente, situa-se no seio do tarso por volta dos 12 anos de idade. Outra queixa comumente relatada é a fadiga ${ }^{(15)}$. Neste levantamento, encontrou-se maior prevalência da deformidade e dor de uma maneira associada (10 casos), seguidos de deformidade isolada (8 casos) e apenas 2 casos devido a dor isolada. A fadiga não ocorreu isoladamente, tendo sido encontrada em oito pacientes, principalmente associada a dor e deformidade (cinco pacientes), deformidade (três pacientes) e dor (um paciente), traduzindo possivelmente o maior gasto energético em deformidade mais acentuada

O tratamento baseia-se no binômio idade e grau de deformidade ${ }^{(15)}$. Após um acompanhamento de 12 a 18 meses, se a deformidade permanecer, órteses são comumente prescritas. Embora saiba-se que estas não impeçam a progressão da doença ${ }^{(15,26)}$, estudos biomecânicos indicam melhoria do alinhamento talo-metatársico e melhor inversão do retropé(9) Patiño e Gerstner ${ }^{(18)}$, estudando cem pés de cinquenta e um pacientes portadores de pé plano valgo idiopático, em um seguimento médio de 22,15 meses, constatou que $68,6 \%$ haviam sido tratados previamente por órteses. Neste estudo, doze pacientes haviam feito uso de palmilhas e botas ortopédicas. Não se observou, entretanto, melhora da deformidade, porém na maioria destes (nove pacientes) houve alívio provisório dos sintomas iniciais, o que sugere uma redução do estresse axial em estruturas mediais, sem, entretanto, agir nos mecanismos fisiopatológicos da doença, por não impedir sua progressão.

Em seu estudo sobre a osteotomia de deslizamento medial em 1971, Koutsogiannis ${ }^{(10)}$, após um acompanhamento de seis anos a três meses, relata a restauração do arco longitudinal em vinte e cinco pés. Em dezessete pacientes, houve melhoria da fadiga e dois maus resultados foram associados à contratu ra do tendão calcâneo. Embora não traga expresso valores dos ângulos radiográficos, relaciona a melhoria estética do pé à redução da subluxação talonavicular. Em dezessete pacientes não houve problema com o uso de calçados após a cirurgia, evidenciando a não progressão da deformidade após a cirurgia.

Na série de Patiño e Gerstner ${ }^{(18)}$, notaram-se $100 \%$ de meIhoria da dor e fadiga, sendo que, 96,1\% dos pacientes não haviam voltado a deformar seus calçados. Conclui o estudo relatando um total de $96 \%$ de bons resultados. Nesta casuística, seguindo a técnica descrita por Koutsogiannis modificada, encontrou-se alívio dos sintomas iniciais em dezessete pacientes.

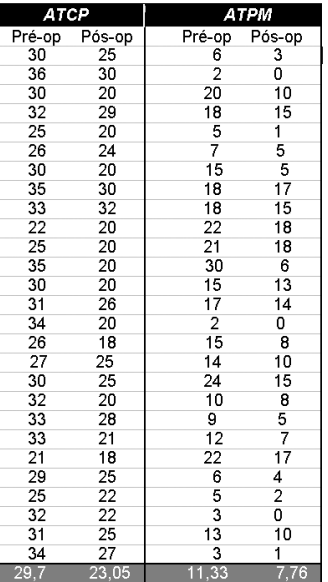
posterior; ATCP, ângulo talocalcaneano na incidência perfil; ATPM, ângulo talo- $1^{\circ}$ metatarso na incidência perfil; pré-op, pré-operatório, pós-op, TCAAP, talocalcaneal angle in anteroposterio metatarsal angle in profile view radiograph; preright side ; $\boldsymbol{L}$, left side; $\boldsymbol{B}$, bilateral.

Tabela 2 - Dados Radiográficos Table 2 - Radiographic data was found in eight patients, mainly associated to pain and deformity (five patients), deformity (three patients), and pain (one patient), possibly translating higher energy expenditure in a sharper deformity.

The treatment is based on the binomium age + degree of deformity (15). After a 12- to 18-month follow-up, should the deformity persist, ortheses should be routinely prescribed. Althou gh it is known that ortheses will not prevent disease progression ${ }^{(15,26)}$, biomechanical studies indicate indicate an improved talar-metatarsal alignment and higher inversion of the hind foot ${ }^{(9)}$. Patiño e Gerstner et al (18) studied one hundred feet of 51 patients with idiopathic pes planovalgus; after an average follow-up of 22.15 months, it was found that $68.6 \%$ had received ortheses. In this study, twelve patients had made previous use of orthopedic soles and shoes. No improvement was noticed as regards deformity, but most (nine) of these patients achieved transient relief of their initial symptoms, suggesting a reduction of the axial stress in medial structures, although this did not influence the pathophysiological mechanisms of the disease, due to the fact that it did prevent its progression.

In his 1971 study on medial slipped osteotomy, Koutsogiannis ${ }^{(10)}$, after a six to three-year follow-up, reports the recovery of the longitudinal arch in 24 feet. Seventeen patients presented improvement in fatigue, while two poor results were associated to calcaneal tendon contracture. Although this does not express radiographic angle values, it does relate esthetic improvement of foot to the reduction of talonavicular subluxation. Seventeen patients had no problems with their shoes after the surgery, proving that the deformity did not evolve.

In their 1990 series of studies, Patiño e Gerstner et al (18) noticed a $100 \%$ improvement in pain and fatigue; also, $96.1 \%$ of the patients had not deformed their shoes again. The study reports a total of $96 \%$ good results. In this population and using the modified Koutsogiannis technique, relief of the early symptoms was achieved in seventeen patients. The longitudinal arch was restored in sixteen patients, and, together with the corrective mean of Kite's angle in 7.73 degrees and Meary's angles in 5.2 degrees, showed an improvement of the talocalcaneal and talocalcânea congruences, respectivamente, proving that the ideally eligible patient to undergo Koutsogiannis medial slipped osteotomy should be the one with mild to moderate hind foot valgus free from degenerative alterations and symptoms limited to the medial appearance of the foot ${ }^{(10)}$.

Patients with more severe deformities and more symptoms usually show an association with tendinous contractures ou ligamental hyperlaxity, so isolated procedures will hardly be successful (1). In this study, two poor results were associated to ligamental hyperlaxity, where severe deformities were found in the 
A restauração do arco longitudinal em dezesseis pacientes, aliados à média corretiva dos ângulos de Kite em 7,73 graus e Meary em 5,2 graus, revelaram melhoria da congruência talocalcaneana e talonavicular respectivamente, demonstrando que o paciente ideal para a osteotomia de deslizamento medial de Koutsogiannis deverá ser o portador de retropé valgo leve ou moderado, livre de alterações degenerativas e sintomas confinados ao aspecto medial do pé(10).

Os pacientes com deformidade mais grave e sintomática costumam ter associados contraturas tendíneas ou hiperfrouxidão ligamentar, sendo que dificilmente procedimentos isolados terão êxito(1). Neste estudo associou-se dois maus resultados à hiperfrouxidão ligamentar em que no período pré-operatório notou-se deformidade grave, acompanhando grande alteração dos eixos axiais do pé. Koutsogiannis ${ }^{(10)}$, em sua casuística, encontrou a persistência da deformidade em quatro casos e atribui a isso a contratura do tendão calcâneo. Sua técnica não é, portanto, eficaz nos casos de maior gravidade, em que fatores etiopatogênicos causem a progressão da doença no período pós-opertório. Fica reservado a estes pacientes procedimentos mais complexos como, por exemplo, a técnica de Evans associada a artrodese subtalar ${ }^{(1)}$.

$\mathrm{Na}$ análise comparativa às demais técnicas, nota-se que, ao realizar o procedimento descrito por Nápoli(15) Guidio e Lare$\mathrm{do}^{(7)}$ no qual realizam-se cunha de subtração de base medial, associada à tenossuspensão dos tibiais para a correção concomitante do valgismo de retropé e da abdução do antepé, fazse necessária a utilização de dois fios de Kirschner para fixação e manutenção da redução dos fragmentos, enquanto que, na técnica em estudo, observou-se a correção simultânea de ambas as deformidades, dispensando procedimentos adicionais em partes moles e estabilidade da redução com o uso de apenas um fio de Kirschner, traduzindo maior estabilidade do deslizamento em relação à cunha de subtração, quando realizada de maneira isolada.

Na técnica de Chambers ${ }^{(3)}$, realiza-se osteotomia do calcâneo abaixo da faceta ântero-lateral, imediatamente posterior à articulação calcaneocuboidea associada ao alongamento do tendão de calcâneo. Embora haja relatos de até 95\% de bons resultados ${ }^{(3,14)}$, notou-se ausência de correção radiográfica em $72,8 \%$ dos casos e estreitamento da talonavicular em $22 \%$ dos casos pacientes. Neste estudo, além da maior simplicidade técnica, houve estreitamentos articulares e obteve-se correção radiográfica em $84,21 \%$ dos pés operados.

Em relação às cirurgias de alongamento da coluna lateral, como o procedimento de Evans ${ }^{(6)}$, no qual adiciona-se enxerto tricortical ao calcâneo e artrodese de distração calcaneocuboidea, amplamente utilizadas no tratamento do pé plano valgo idiopático, relatam-se altas taxas de complicação. Thomas e pre-operative period, following a major alteration in the foot shaft. In the cases studied by Koutsogiannis (10), the deformities persisted in four patients and were deemed related to the calcaneal tendon contracture. Therefore, the author's technique is effective in the more severe cases where etiopathogenic factors cause the progression of the disease in the post-operative period. These patients should undergo more complex procedures such as, for example, the Evans technique associated with subtalar arthrodesis ${ }^{(1)}$.

A comparison of this technique with other techniques shows that in the procedure described by Napoli (15) Guidio and Laredo ${ }^{(7)}$, where a medial base subtraction wedge was used in association with tibial tenosuspension to simultaneously correct a hind foot valgus and abduct the forefoot, it was necessary to use Kirschner threads to fix and maintain the reduction of fragments, while in the technique used in our study simultaneous correction of both types of deformities was achieved, with no need of additional procedures for the soft parts, and stability of the reduction using one Kirschner only, mirroring a higher slipping stability as action wedge, when performed in isolated orm.

In the Chambers ${ }^{(3)}$ technique the calcaneal osteotomy is performed below the anterolateral facet, immediately behind to the calcaneal-cuboid-joint associated with the elongation of the calcaneal tendon. Although there are reports of up to $95 \%$ of good results ${ }^{(3,14)}$, radiographic correction was absent in $72.8 \%$ of the cases and talonavicular narrowing in $22 \%$ of the patients. In this study, joint narrowing and radiographic correction were achieved in $84.21 \%$ of the operated feet, besides the fact that the technique was more simple.

As to lateral column elongation surgeries such as the Evans procedure ${ }^{(6)}$, where a tricortical graft is added to the calcaneus and calcaneal cuboid distraction arthrodesis, widely used in the management of idiopathic pes planovalgus, high complication rates are reported. In 2001 Thomas et al (24) performed comparative studies on both techniques using 35 feet, where a healing delay was found in $16.5 \%$ of the cases. Also, studies on the Evans ${ }^{\left({ }^{6}\right)}$ procedure Rathjen Mubarak ${ }^{(20)}$ reported stress fractures with calcaneal medial slipping technique associated with cuboid addition wedge, sixteen results were rated good in twenty-four operated feet, with radiographic undercorrection in seven feet and overcorrection in three feet, while in this study correction occurred in seventeen feet, besides the fact that a single bone procedure was employed which does not require grafting; none of the operated feet showed overcorrection and no delays were observed as regards union or pseudoarthrosis.

Finally, studies performed in cadavers suggested biomechanical changes in the ankle after a calcaneal internal slipped osteotomy. Michelson et al (13) studied eight specimens and found 
Wells ${ }^{(24)}$ realizaram estudos comparativos de ambas as técnicas em trinta e cinco pés, notando retardo de consolidação em $16,5 \%$ dos casos. Há também relatos de fraturas de estresse em estudos do procedimento de Evans ${ }^{(6)}$. Rathjen e Mubarak ${ }^{(20)}$ ao realizarem a técnica de deslizamento medial do calcâneo, associada à cunha de adição no cubóide, relata dezesseis bons resultados em vinte e quatro pés operados, dos quais obteve sub correção radiográfica em sete pés e sobre correção em três pés, enquanto que, no presente estudo, além de ser utilizado um procedimento ósseo único, sem necessidade de enxertia, ocorreu correção em dezessete pés, não sendo observada sobre correção em nenhum pé operado, sem nenhum retardo de união ou pseudoartrose.

Finalmente, estudos cadavéricos têm sugerido alterações biomecânicas no tornozelo após osteotomia de deslizamento interno do calcâneo. Michelson et al.(13), estudaram oito espécimes e verificaram que, em dorsiflexão máxima, houve aumento em $76 \%$ da rotação interna e aumento do varismo em $425 \%$, podendo predispor a degenerações articulares. Estudos sobre a técnica a longo prazo poderão esclarecer tais fatos.

\section{CONCLUSÃO}

A osteotomia de deslizamento medial de Koutsogiannis mostrou melhora estética do pé e alívio sintomático. Houve correção radiográfica dos ângulos de Kite (talocalcaneano) e taloprimeiro metatarso, podendo ser indicada como procedimento isolado para a correção de pé plano valgo flexível idiopático leve e moderado em crianças de dez a treze anos. that in maximum dorsiflexion there was a $76 \%$-increase in the internal rotation and a $425 \%$-increase in varus deformities, which may predispose to joint degeneration. Further studies on the use of this technique in the long range might clear such facts.

\section{CONCLUSION}

Koutsogiannis' medial slipped osteotomy showed an improvement in the foot aesthetics and symptom relief. A radiographic correction of the talar calcaneal (Kite's) and talar-first metatarsal angles was found, which could be indicated as an isolated procedure to correct mild to moderate idiopathic flexible pes planovalgus in 10- to 13-year old children.

\section{REFERÊNCIAS BIBLIOGRÁFICAS}

1. Bruyn JM, Cerniglia MW, Chaney DM. Combination of Evans calcaneal osteotomy and STA-Peg arthrodesis for correction of severe pes valgo planus deformity. J Foot Ankle Surg 38:339-346, 1999.

2. Catanzariti AR, Lee MS, Mendicino RW. Posterior calcaneal displacement osteotomy for adult acquired flatfoot J Foot Ankle Surg 39:2-14, 2000

3. Chambers $E$. An operation for the correction of flexible flatfeet of adolescents. Western J Surg Obs Gynecol 54:77-86, 1946.

4. Cormack $A$, Niki $H$. Two reconstructive techniques for flatfoot deformity comparing contact characteristics of the hindfoot joints. J Foot Ankle Surg 19:452-461, 1998.

5. Davitt JS, Morgan JM. Stress fracture of the fifth metatarsal after Evans calcaneal osteotomy: a report of two cases. Foot Ankle Int 19:710-712, 1998.

6. Evans D. Calcaneo-valgus deformity. J Bone Joint Surg Br 57: 270-278, 1975.

7. Guidio A, Laredo J. Tratamento cirúrgico do pé plano postural. Estudo de 40 casos. Folha Med 96:367-370, 1988

8. Hoke M. An operation for the correction of extremely relaxed flat feet. J Bone Joint Surg Am 30:116-138, 1948

9. Kitaoka H, Luo Z, Kura H. Effect of foot ortheses on 3-dimensional kinematics of flatfoot: a cadaveric study. Arch Phys Med Rehabil 83:876-879, 2002.

10. Koutsogiannis E. Treatment of mobile flat foot by displacement osteotomy of the calcaneus. J Bone Joint Surg Br 53:96-100, 1971.

11. Lowman $\mathrm{CL}$. An operative method for correction of certain forms of flat foot. JAMA 3:1500-1502, 1923.

12. Meary R, Lacheretz M, Rigault P. Symposium sur le piet plat. Annais Orthop Ouest 1:57-61, 1969

13. Michelson J, Mizel M, Jay P. Effect of medial displacement calcaneal osteotomy on ankle kinematics in a cadaver model. J Foot Ankle Surg 19:132-136, 1998.
14. Miller GR. The operative treatment of hypermobile flatfeet in the young child. Clin Orthop 122:95-101, 1977

15. Nápoli M. Osteotomia cuneiforme do Calcâneo para correção dos pés planos inveterados: resultados preliminares. Rev Paul Med 77:213-224, 1971.

16. Nery C, Sodré H, Pinto J. Pé plano valgo postural. Folha Med 112:39-42 1996.

17. Otis J, Deland J. Medial arch after medial displacement calcaneal osteotomy: an in vitro study . J Foot Ankle Surg 20:222-226, 1999.

18. Patiño E, Gerstner J. Pie plano sintomático. Tratamiento con osteotomía de Koutsogiannis. Rev Colomb Ortop Traumatol 6:97-106, 1992.

19. Pomeroy $G$, Manoli A. A new operative approach for flatfoot secondary to posterior tibial tendon insufficiency : a preliminary report. J Foot Ankle Surg 18:206212, 1997

20. Rathjen K, Mubarak M. Calcaneal-cuboid-cuneiform osteotomy for the correction of valgus foot deformities in children. J Pediatr. Orthop 18:775-782, 1998 21. Rose GH. Correction of the pronated Foot. J Bone Joint Surg Br; 44:642-648, 1962.

22. Staheli LT, Chew D, Corbett M. The longitudinal arch. A survey of eight hundred and eighty-two feet in normal children and adults. J Bone Joint Surgery Am 69:426-428, 1987

23. Tachdjan,M.O. Pé planovalgo flexível (pé plano, pé chato). Ortopedia Pediátrica 2 ed. São Paulo: Manole; 1995. Vol. 4, cap. 7 P. 2733-2771.

24. Thomas R, Wells B. Preliminary results comparing two methods of lateral column lengthening. J Foot Ankle Surg 22:19-107, 2001.

25. Viladot PA. Dez lições de patologia do pé São Paulo: Roca, 1986 p.202-204 26. Wenger D, Mauldin D, Speck GJ et al. Corrective shoes and inserts as treatment for flexible flatfoot in infants and children. J Bone Joint Surg Am 71: 800810,1989 